\title{
Radiations and male fertility
}

\author{
Kavindra Kumar Kesari ${ }^{1}$, Ashok Agarwal ${ }^{2^{*}}$ (D) and Ralf Henkel ${ }^{3}$
}

\begin{abstract}
During recent years, an increasing percentage of male infertility has to be attributed to an array of environmental, health and lifestyle factors. Male infertility is likely to be affected by the intense exposure to heat and extreme exposure to pesticides, radiations, radioactivity and other hazardous substances. We are surrounded by several types of ionizing and non-ionizing radiations and both have recognized causative effects on spermatogenesis. Since it is impossible to cover all types of radiation sources and their biological effects under a single title, this review is focusing on radiation deriving from cell phones, laptops, Wi-Fi and microwave ovens, as these are the most common sources of non-ionizing radiations, which may contribute to the cause of infertility by exploring the effect of exposure to radiofrequency radiations on the male fertility pattern. From currently available studies it is clear that radiofrequency electromagnetic fields (RF-EMF) have deleterious effects on sperm parameters (like sperm count, morphology, motility), affects the role of kinases in cellular metabolism and the endocrine system, and produces genotoxicity, genomic instability and oxidative stress. This is followed with protective measures for these radiations and future recommendations. The study concludes that the RF-EMF may induce oxidative stress with an increased level of reactive oxygen species, which may lead to infertility. This has been concluded based on available evidences from in vitro and in vivo studies suggesting that RF-EMF exposure negatively affects sperm quality.
\end{abstract}

\section{Introduction: History and sources of microwaves}

Radiation can be characterized into ionizing and non-ionizing radiations, of which the latter is differentiated in two forms: 1) extremely low frequency (ELF) or power line $(60 \mathrm{~Hz})$ electromagnetic fields (EMFs), and 2) radio frequency $(\mathrm{RF})$ EMFs - which are produced by wireless radio waves/microwaves products.

The biological effects of microwave radiations effectively begin with the development of radar early during World War II. No harmful effects of microwaves were detected prior to this time and are also not in the list of a general environmental problems. Prausnitz and Susskind were the first who reported the effects of microwave radiation on the testicular organ in 1962 [1]. Since early 1962, many man-made devices are now in use and the most common source for microwaves are transmission lines $(50-60 \mathrm{~Hz})$, computer monitors $(60-90 \mathrm{~Hz})$, AM radio transmissions $(530-1600 \mathrm{KHz}), \mathrm{FM}$ radio transmissions $(88-108 \mathrm{MHz})$, television transmissions $(50-700 \mathrm{MHz})$, hand phones

\footnotetext{
* Correspondence: agarwaa@ccf.org; http://www.ClevelandClinic. Org/ReproductiveResearchCenter

${ }^{2}$ American Center for Reproductive Medicine, Cleveland Clinic, Mail Code X-11, 10681 Carnegie Avenue, Cleveland, OH 44195, USA

Full list of author information is available at the end of the article
}

(850 MHz-2.4 GHz), microwave ovens (2.45 GHz), laptops and Wi-Fi $(2.4 \mathrm{GHz})$.

The frequencies in the range of $100 \mathrm{kHz}$ to $300 \mathrm{GHz}$ refer to RF and represent only a part of the electromagnetic spectrum. Figure 1 shows the sources of radiofrequency electromagnetic field (RF-EMF) exposure affecting sperm parameters. In the list of new technologies, intermediate frequency (IF) has been listed as newest source of exposure to electro-magnetic fields. This frequency range falls between the low frequency (low frequency- $0.1 \mathrm{~Hz}-1 \mathrm{kHz}$ ) and the radio frequency (RF) $(10 \mathrm{MHz}-300 \mathrm{GHz})$. Major sources of this range are airport security scanners and anti-theft devices operated at the exits of shops.

On the other hand, radiations such as X-rays, $\gamma$-rays and $\alpha$-particles are forms of ionizing radiation [2]. Ionizing radiation is much more dangerous than non-ionizing radiations. Significant sources of ionizing $\gamma$-rays include natural sources such as the decay of uranium in the earth, cosmic rays, the sun and radon gas, while artificial or manmade sources include radioactive waste, X-rays from medical procedures etc.

Radiation induced cancer is triggered by chromosomal damage or genomic instability [3]. An increase in chromosomal abnormalities may be a result of exposure to 


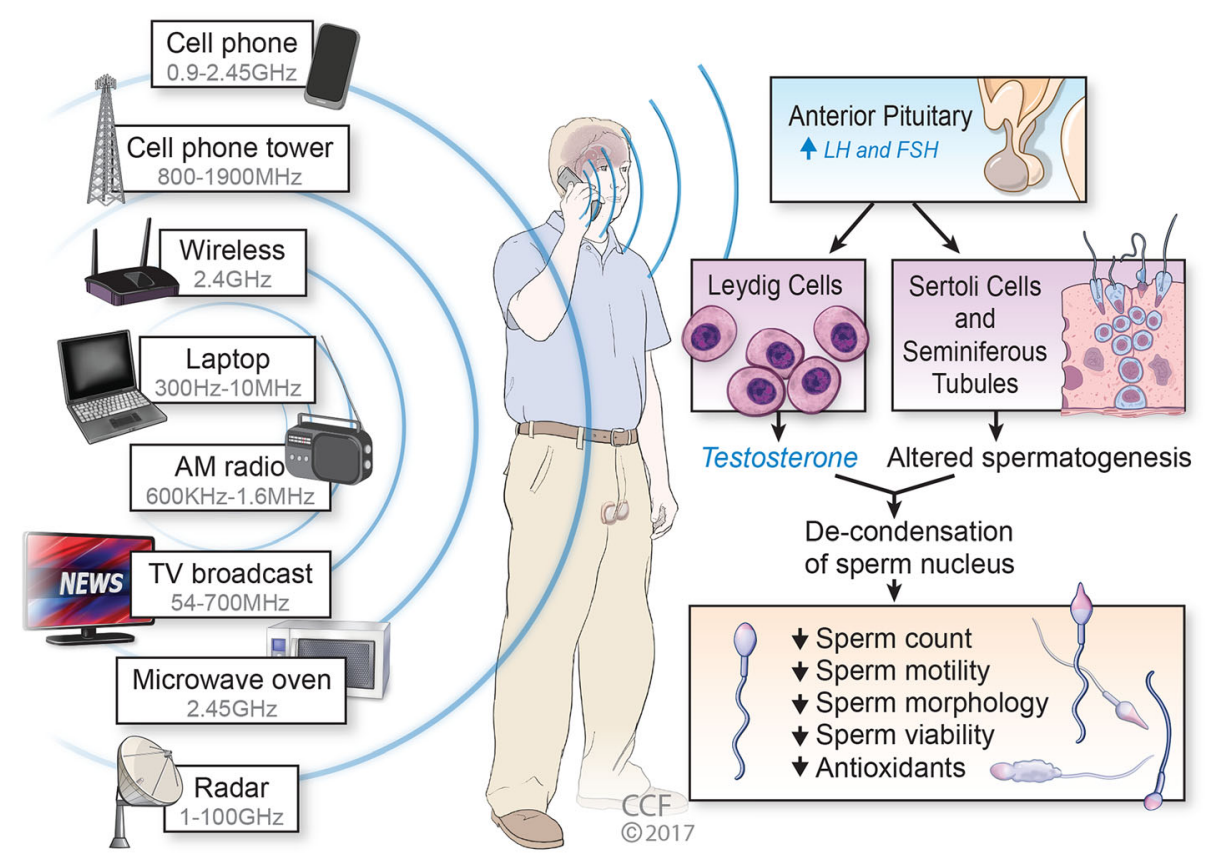

Fig. 1 Diagrammatic representation of various source of RF EMF exposure effect on brain and testicular organ and deleterious outcome

radiation, which was first reported by Martin et al. [4]. The most radiosensitive organ reported is the male testis with the germinal epithelium including the spermatogonia which are more sensitive to radiation exposure than other cells $[5,6]$.

The effects of IR on reproduction are of growing concern as the number of people exposed to radiation via medical procedures and environmental exposures is significantly increasing. Data reviewed by Yousif et al. [7] obtained from 31 studies report an association between occupational exposures to IR and either the incidence of or mortality from testicular cancer. Similar data were obtained for non-ionizing radiation from 9 studies. Since radiations have a broad range of wavelengths, it is impossible to cover all the existing ionizing and non-ionizing radiations in a single article. Further, the available data on ionizing radiation clearly indicate its role in the development of cancers, such as testicular cancer. In contrast, much less clear information is available on non-ionizing radiation. Therefore, the focus of our review is more to explore the effects of non-ionizing radiation such as RF-EMF on male fertility. This includes frequencies used for cell phones, laptops, computers, microwave ovens and some other higher frequency range; this includes the RF-EMF-induced biological effects and potential mechanisms on the male reproductive system.

The networking of RF-EMF-assisted devices like cell phones, $\mathrm{Wi}-\mathrm{Fi}$, microwave ovens, and laptops is increasing drastically and its association with male infertility has been reported [8-11]. Based on sufficient evidence, it has now been increasingly realized that RF-EMF radiation is pervading the environment and has therefore been mentioned under the terms "electro-pollution" or "electro-smog" in the list of other environmental pollutants (air, water, soil, and noise pollution) [12].

The International Agency for Research on Cancer [13, 14] classified RF in group $2 B$ as 'possibly carcinogenic' to humans. The guidelines on the specific absorption rate (SAR) of mobile phones are legally limited to $2.0 \mathrm{~W} / \mathrm{kg}$ by the International Commission on Non-Ionizing Radiation Protection reported [15], but still the SAR level varies from country to country. SAR is a standard unit or rate at which RF-EMF energy is imparted to an element or mass to measure the penetration of energy within human tissues.

The amount of SAR absorbed by human tissue depends on many factors such as the frequency, intensity, polarization and duration of exposure [16] and most importantly the position of devices while used. A higher radiation absorption rate could be observed while talking on phone, keeping phone near head or in pants pocket, using laptop computer on lap connected with Wi-Fi and frequently use of microwave ovens. Agarwal et al. suggested that using mobile phones adversely affects the quality of semen by decreasing the sperm count, motility, viability and morphology, which might contribute to male infertility [17]. Consequently, Desai et al. concluded that RF-EMF exposure might induce DNA damage due to increased oxidative stress, which may 
accelerate spermatozoal cell death and promote testicular carcinogenesis [18]. Many animal studies on the use of mobile phones are linked to a reduction in sperm count [9] and motility [19], suggesting an impairment of male fertility. Similarly, in humans, Agarwal et al. reported that the continuous use of mobile phones is associated with decreased motility, sperm concentration, morphology and viability [20]. The most significant studies on the effect of RF-EMF emitted from different sources (cell phones, microwave ovens, laptops, and Wi-Fi devices) on animal and human fertility pattern are summarized in Table 1 [21-37].

The literature shows that studies investigating the deleterious effects of cell phone and microwave exposure on male reproductive organs are mainly concentrating on sperm parameters $[9,25,38]$. However, till date, no possible mechanisms on how RF-EMF radiation interacts with the male reproductive organs and thereby affect the fertility pattern are known. Some of the concerns are listed and discussed in detail by introducing 1) biophysics of RF-EMF radiation, 2) effect of RF-EMF on sperm parameters 3) role of kinases in cellular metabolism 4) genotoxic effect of EMF leading to genomic instability 5) RF-induced oxidative stress 6) RF-EMF effect on reproductive endocrine system, and 7) protective measures for these radiations and future recommendations.

\section{Biophysical parameters of RF-EMF}

The biophysical parameters describe the physical and biological factors, which determine cellular radio-sensitivity of RF-EMF exposure by measuring the absorption rate of the radiation. In theory, the EMF must penetrate the exposed biological system and induce internal EMFs to cause a biological response. On the other hand, the penetration depth or RF radiation absorption depends on incident field parameters (like intensity, power density), zone of exposure, shape, geometry, and orientation of the object; and configuration of the radiation, e.g., how close is the object from the RFR source? [39]. These parameters directly or indirectly participate in free radical formation by increasing ROS levels, which have been found to be a factor for DNA damage. Kumar et al. have reported sperm DNA damage after 3G mobile phone exposures [26].

DNA damage is one of the serious concerns in respect to infertility or testicular cancer. The question, however, is how such a low frequency RF radiation may cause DNA damage? This question is not easy to answer, but it is assumed that a RF electro-magnetic field is classified as non-ionizing radiation because the photons do not have sufficient energy to break chemical bonds or directly ionize biological molecules [39]. Therefore, it is generally accepted that the EMF energy is not enough to damage DNA directly, thus indirect mechanisms, such as the free radical hypothesis, have been proposed to explain EMF-induced DNA damage [40-42]. Cell phones and its transmission towers, are both equally responsible for health effects, as cell phones emit radiations to nearby relay base stations or antennas. Our bodies act as antennas that absorb the radiation and convert it into alternating eddy currents [43]. Cell phone radiation is generated in the transmitter, and is emitted through the antenna in the form of radio waves $[16,39,44]$. The impact of this RF-EMF on the human body is measured via a standardized unit called the SAR. The rate of energy absorbed by or deposited per unit mass per unit time is the SAR and E-filed can be calculated by-

$$
\operatorname{SAR}(W / K g)=\sigma E^{2} / \rho
$$

Where sigma $(\sigma)$ is the conductivity of the liquid and rho $(\rho)$ is the density of liquid. The measured E-field values and SAR distribution are $1 \mathrm{~g}$ and $10 \mathrm{~g}$ mass averaged SAR values.

When a biological body or tissue is exposed to RF-EMF, the RF energy is scattered and attenuated as it penetrates body tissues. Energy absorption is largely a function of the radiation frequency and the composition of the exposed tissue. The problem of physics in respect to EMF exposure is of penetration depth. The higher absorption rate of radiations emitting from cell phone is more absorbed inside the tissue while making a cell phone call or using electro-magnetic devices.

Testicles are very sensitive to these radiations because of the development and maturation processes of sperm taking place in the testicles. It is also well established that the developing phase of the brain and the testicles are very sensitive to radiation, which may cause severe damages in the form of genotoxic effects $[9,25,26,45]$. Several studies suggest that microwave radiations are potentially strong enough to penetrate the brain cranium, and nearly $40 \%$ of these can reach deeper into the brain [46, 47]; penetration depths of $4-5 \mathrm{~cm}$ are assumed [48, 49]. The same applies to the testes.

During testicular developmental stages, the penetration depth is not the sole factor, but also i) exposure time; ii) duration of exposure (i.e. number of exposure days); iii) the greater number of undeveloped cells exposed to microwaves; and iv) the water content of the organ (the greater the amount of water in an organ, the greater will be the effect of the microwave radiation). Several studies also reported that EMF-induced morphological changes are also depending on the type, dose, mode and duration of the EMF-exposure [50-54]. Therefore, it is imperative to explore biophysical parameters related to RF-EMF exposure and causative factors, first. 
Table 1 Studies ON REPRODUCTION: IN VITRO \& IN VIVO

\begin{tabular}{llll}
\hline Subject/ species & Exposure Parameters & Findings & References \\
\hline Male swiss albino mice, $n=8$ & $902.4 \mathrm{MHz} 4 \mathrm{~h} / 8 \mathrm{~h} /$ day & Significant increase in abnormal cells, & Pandey et al. 2017 [21]. \\
& for 35 days; SAR 0.0516 W/kg & $\begin{array}{l}\text { spermatogonia and decreased } \\
\text { spermatids. Significant histological }\end{array}$ & changes in seminiferous tubules. \\
& $\begin{array}{l}\text { Significant increase in DNA damage } \\
\text { of both 4 \& } 8 \text { h exposure. }\end{array}$ & &
\end{tabular}

Sprague Dawley male rats, $n=8 \quad 900 \mathrm{MHz}$ mobile phone frequency; $1 \mathrm{~h} /$ day for 30 days; SAR $0.025 \mathrm{~W} / \mathrm{kg}$

Human spermatozoa (in vitro), $n=26$

$850 \mathrm{MHz}$ continuous for $1 \mathrm{~h}$; SAR $1.46 \mathrm{~W} / \mathrm{kg}$

Human spermatozoa (in vitro), $n=32$

Male Wistar rats, $n=6$

Male Wistar rats, $\mathrm{n}=6$

Male Male Wistar rats, $\mathrm{n}=6$ in each group

Male Wistar rats, $\mathrm{n}=3$ each group

Male Wistar Rats, $n=6$ each group

Male Wistar rats, $\mathrm{n}=6$

Male Wistar rats, $\mathrm{n}=6$

Male Albino Wistar rat

Human semen

Male Albino Wistar rat
$2.45 \mathrm{GHz} / 0.014 \mathrm{~W} / \mathrm{Kg}$ (2 h/day for 60 days). PEMF $100 \mathrm{~Hz}$

900-1800 MHz; intermittent every 10 min for 5 h;

$2.45 \mathrm{GHz} / 0.14 \mathrm{~W} / \mathrm{Kg}(2 \mathrm{~h} \mathrm{a}$ day for 45 days)

$1910.5 \mathrm{MHz} / 1.34 \mathrm{~W} / \mathrm{kg} 60$ days, two hours each day (6 days a week)

GSM $900 \mathrm{MHz} / 0.9 \mathrm{~W} / \mathrm{Kg}$

(2 h/day for 45 days

10GHz/ flux density $0.21 \mathrm{~mW} / \mathrm{cm}^{2} /$ SAR: $0.014 \mathrm{~W} / \mathrm{kg} /$ Continuous $2 \mathrm{~h} /$ day for 45 days

$2.45 \mathrm{GHz} / 0.11 \mathrm{~W} / \mathrm{Kg}$

( 2 h/day for 35 days)

RF-EMR 900/ $0.9 \mathrm{~W} / \mathrm{kg}$

$900 \mathrm{MHz}$ GSM

(60 min/day for 3 months)

RF-EMR $850 \mathrm{MHz} / 1.46 \mathrm{~W} / \mathrm{kg}$ (for $60 \mathrm{~min}$ )

GSM $0.9 \& 1.8 \mathrm{GHz} / \mathrm{SAR}-?$ (1 h/day for 28 days)
( $2 \mathrm{~h} /$ day for 35 days)
Significant increase in apoptosis and changes in the levels of SOD, GPx,

CAT, LPO. Cincludes that $900 \mathrm{MHz}$ could alter histology, the oxidative status and apoptosis induction in testes.

In group 1 of normal sperm, the gene and protein expression of clusterin and DNA fragmentation were increased significantly in EMF exposed sperm. Concluded detrimental effect of mobile phone on sperm parameters.

Significantly increase in DNA fragmentation and non-progressive motility and reduction in progressive motility in exposed sperm.

A significant increase in DNA SB, protein carbonyl content, ROS, XO, MDA apoptosis and significant decrease in testosterone, $\mathrm{LDH}-\mathrm{X}$ were observed in microwave exposed group. A treatment with melatonin prevent oxidative damage in all above parameters.

Significant decrease in sperm count, seminiferous diameter, testicular weight and increase in DNA single strand break and MDA level.

Decrease sperm count, increased apoptosis, micronuclei and ROS. Affect the level of antioxidant enzymes and testosterone level. Morphological changes also observed under TEM.

Decreased melatonin, testosterone and increased creatine kinase, capases significantly in exposed group. PEMF showed therapeutic impact against microwave exposure.

Significant increase in ROS level, apoptotic cells and decrease in percentage of $\mathrm{G}_{2}$ phase /mitosis phase of cell cycle and histone kinase enzyme activity.

Significant decrease in sperm count, changes in antioxidant enzyme $(\mathrm{SOD}$ GPx, CAT) and DNA fragmentation exceed to cell apoptosis.

Statistically significant reduction in Protein Kinase $C$ activity, sperm count and increased apoptotic sperm cells.

Long term mobile phone radiation exposure leads to reduction in serum testosterone level

Motility \& viability significantly decreased, increased in ROS level, decreased in ROS-TAC score

Reduced \% of motile sperm. Increase LPx, GSH content of testis and epididymis.
Odaci and Ozyilmaz 2016 [22]

Zalata et al. 2015 [23]

Gorpinchenko et al. 2014 [24]

Meena et al. 2014 [25].

Kumar et al. 2014 [26]

Kesari et al. 2011, Kesari and Behari 2012 [27, 28]

Kumar et al. 2011 [29]

Kumar et al. 2011 [30]

Kesari and Behari 2010 [31]

Kesari et al. 2010 [32]

Meo et al. 2010 [33]

Agarwal et al. (2009) [34]

Mailankot et al. 2009 [35] 
Table 1 Studies On ReProduction: IN VITRO \& IN VIVo (Continued)

\begin{tabular}{llll}
\hline Subject/ species & Exposure Parameters & Findings & References \\
\hline Human Spermatozoa & $71.8 \mathrm{GHz} / 0.4-27.5 \mathrm{~W} / \mathrm{Kg}$ & Both [power density and frequency range & De luliis et al. 2009 [36] \\
(exposure time $16 \mathrm{~h}$ ). & $\begin{array}{l}\text { spermato mitochondrial ROS in human } \\
\text { and viability and cause DNA fragmentation }\end{array}$
\end{tabular}

Sprague Dawley rats $\quad$ RF-EMR $1.9 \mathrm{~Hz} @$ distance of $1 \mathrm{~cm}$ for $6 \mathrm{~h} /$ day $\times 18$ weeks
Significant decrease in sperm motility also majority of sperm cells in the exposure group were dead, where as in the control group the majority were alive with constant, active motility

\section{The effect of RF-EMF exposure on sperm parameters}

In light of reports indicating that in $20057.4 \%$ of couples in the United States were infertile [55], and that this number is predicted to increase as high as $15 \%$, particularly in industrialized countries [56], one can link the increasing usage of RF devices such as cell phones or Wi-Fi, with R F-EMF induced sperm damages as this is closely related to infertility. Although, there are numerous other factors such as sperm quality, sperm count, motility and morphology impair with increasing age, and lifestyle factors for example alcohol consumption, cigarette smoking that may affect fertility pattern in both male and female, frequent use of cell phone or EMF devices contribute markedly to this poor semen quality (Figure 1).

Apart from this, cell phone usage has been linked to decreases in progressive motile sperm count [20] motility [20] and viability [20,34], as well as to increases in ROS [29] and abnormal sperm morphology. Recent evidence also shows that Wi-Fi from laptops negatively affects sperm quality [8]. EMF is also responsible for the decrease in fertilization rate [57], spermatogenic cell numbers and trigger apoptosis [58, 59], reduced sperm quality [60], hormonal changes in the testis [20,61], and may give rise to fetal loss and developmental impairments in the embryonic period $[45,62]$ (Table 2) $[9,20$, $25,26,28-32,34,38,63]$.

\section{Sperm count}

Radio-frequency electro-magnetic field exposure from cell phones or other sources of microwaves adversely affect male fertilizing potential of spermatozoa [29]. There are several techniques available for the measurement of sperm count like, hemocytometer, flowcytometry and cell counter. Using flowcytometry, Kesari et al. showed a significantly $(P<0.0001)$ decreased percent of sperm count $(61.33 \pm 3.68 \%$ vs. $31.14 \pm 13.6 \%)$ and an increased percentage of apoptotic cells (5.93 \pm $1.64 \%$ vs. $13.15 \pm 1.26 \%$ ) after cell phone exposure ( $2 \mathrm{~h}$ /day for 35 days) in an animal study [9]. In addition to cell phone radiation, the exposure of male Wistar rats to Wi-Fi connected laptop computers (EMF, 1.15 micro Tesla, $\mu \mathrm{T}$ ) for $7 \mathrm{~h} /$ day for 1 week also reduced sperm count and motility [64]. Other studies have also linked RF-EMF $[34,37,61,65,66]$ or cell phone radiation [67-69] to deleterious effects on the testes. Such radiation exposure may create a state of oxidative stress and stimulates free radical generation by the sperm mitochondria [67].

\section{Sperm motility and morphology}

There is also a list of studies indicating the negative influence of RF-EMF on sperm motility and morphology. Several authors found that carrying GSM phones in the trouser pocket or on the belt decreased rapid progressive motility of sperm [70, 71]. Kesari and Behari demonstrated that males who use mobile phones exhibit increased rates of abnormal sperm morphology [28]. Several groups showed that men using mobile phones have decreased sperm concentration, motility, normal morphology, and viability [16, 28, 37, 72, 73]. Further, Luo et al. [74] showed that RF-EMF exposure is directly affecting the testes by causing a significant decrease in the diameter and weight of the seminiferous tubules as well as the mean height of the germinal epithelium and pathological and physiological changes in testicular tissues, respectively, thus, giving evidence for the growing concerns of increasing incidences of infertility $[17,26]$.

The link between the exposure to RF-EMF and testicular pathologies and decreasing sperm quality is most probably oxidative stress by increasing levels of free radicals or superoxide anion as a decrease in sperm motility and viability is triggered by increasing concentrations of superoxide anion $\left({ }^{\circ} \mathrm{O}_{2}{ }^{-}\right)$[34]. Free radicals oxidize membrane phospholipids extracellularly, thus causing decreased viability and reduced membrane fluidity with impaired motility.

\section{Role of kinases in sperm cell cycle and apoptosis}

Apoptosis plays an important role in adjusting the appropriate number of proliferating germ cells associated with the surrounding Sertoli cells during spermatogenesis $[75,76]$. Apoptosis or programmed cell death in the tissues of an organism is an important and inevitable event in the remodeling of tissues during development and spermatogenesis [77]. Cell cycle analysis by flow 


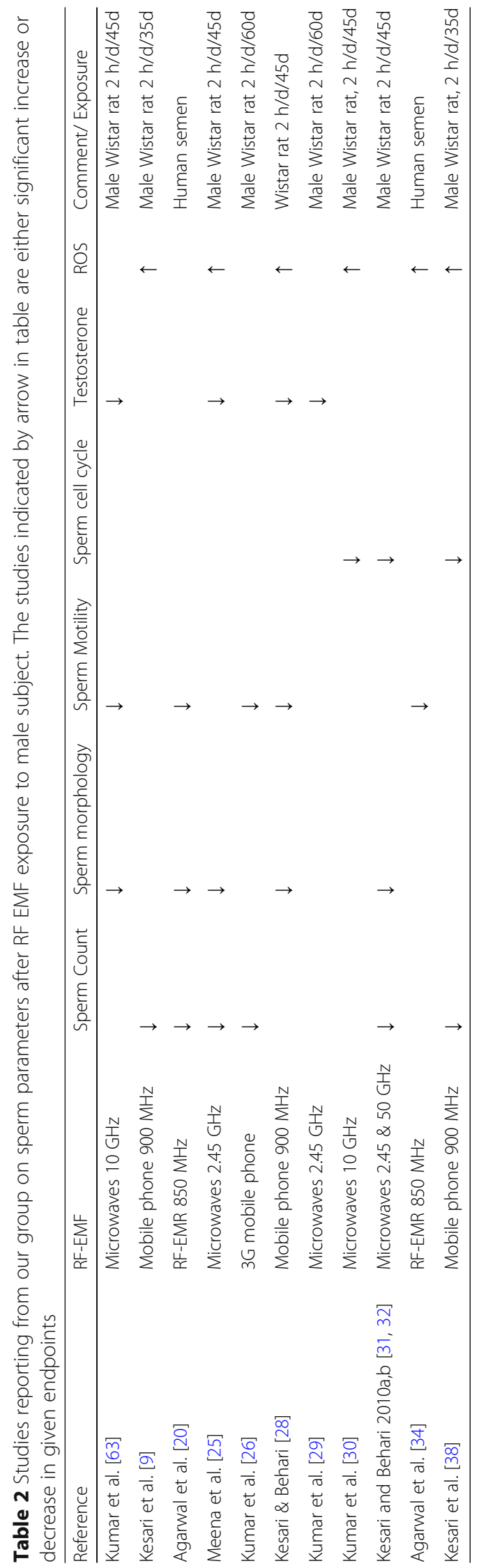


cytometer has confirmed these results because EMF exposure induces the appearance of a sub-G1 apoptotic peak, which is characteristic of DNA fragmentation in spermatozoa [30]. Cell phone radiation exposure showed a significant decrease in $\mathrm{G}_{0}-\mathrm{G}_{1}$ phase of sperm cell cycle $(3.26 \% \pm 1.64 \%: P=0.042)$ and $\mathrm{G}_{2} / \mathrm{M}(15.11 \% \pm 1.41 \%: P$ $=0.022)$ as compared to the control group $(4.12 \% \pm$ $0.58 \%)$ and $\mathrm{G}_{2} / \mathrm{M}(18.84 \% \pm 3.05 \%)$, respectively [34]. An increased level of apoptotic sperm was detected after exposure to $2.45 \mathrm{GHz}(14.30 \% \pm 1.92 \%)$ and mobile phone $(13.15 \% \pm 1.25 \%)$ as compared with sham exposed group $(7.43 \% \pm 1.30 \%)$ and $(5.93 \% \pm 1.64 \%)$, respectively $[9,31]$.

Spermatogenesis is an active proliferative process consisting of two phases: the mitotic and meiotic phase. The cell cycle is regulated by a control system formed by molecules that trigger and coordinate key events. These molecules act primarily at two important check points in the cell cycle, G0 to G1, and G2 to M [16]. Initiation of the $\mathrm{M}$-phase in the sperm cell cycle requires a protein kinase complex consisting of a catalytic sub-unit $[78,79]$ and regulatory sub-unit. Assessment of the catalytic activity of a specific protein kinase plays an important role in elucidating signal transduction pathways, which may affect cell behavior.

Kesari et al. have investigated a significant $(P=0.003)$ decrease in the level of sperm PKC activity after mobile phone exposure $\left(2876 \pm 617.9 \mathrm{P}^{32}\right.$ counts/mg protein) as compared to the control group $\left(3013 \pm 520.67 \mathrm{P}^{32}\right.$ counts $/ \mathrm{mg}$ protein, where $\mathrm{P}^{32}$ is radioactive phosphorus-32 labeled ATP) [9]. Several other studies also reported a decline in sperm motility together with a decrease in PKC activity [80,81]. This could mediate the cellular response to extra-cellular stimuli involved in proliferation, apoptosis, decreased sperm count, and exocytotic discharge in a number of non-neuronal cells i.e. sperm [31, 82]. Kesari et al. have reported a significant decline $(P=0.006)$ in sperm histone kinase activity in a microwave-exposed group (3659.08 $\pm 1399.40 \mathrm{P}^{32}$ counts/mg protein) as compared to the sham exposed one $\left(5374.91 \pm 1366.91 \mathrm{P}^{32}\right.$ counts/mg protein) [38]. Decrease in histone H1 kinase activity just before the entry of differentiating cells into the M-phase, suggesting an universal role of $\mathrm{Cdc} 2 / \mathrm{Cdk} 2$ (cell division cycle/cyclin-dependent kinase) kinase to regulate the G2/M transition [34]. Kumar et al. [30] and Kesari et al. [9] demonstrated that depletion in the activity of both histone kinase and protein kinase may serve as a measure of microwave EMF's ability to affect spermatogenesis and sperm cell cycle. Kumar et al. has also investigated a significantly increased $(P<0.001)$ level of sperm creatine kinase in the microwave-exposed group $(0.24 \pm$ $0.10 \mathrm{IU} / 10^{8}$ spermatozoa) compared to the sham group $\left(0.04 \pm 0.03 \mathrm{IU} / 10^{8}\right.$ spermatozoa) [29].

In spermatozoa, creatine kinase is localized in the mitochondria of the midpiece region [83]. Creatine phosphate serves as a donor for the re-phosphorylation of adenosine diphosphate (ADP) into ATP, which supports flagellar dynein/adenosine triphosphate and sperm quality [84]. Since differences in the creatine kinase activity reflect differences in sperm ATP concentrations and ATP/ADP ratios [84], it can be suggested that protein kinase $\mathrm{C}$, histone kinase and creatine kinase play an important role in cell metabolism and spermatogenesis and any changes in sperm kinases due to RF-EMF or other factors may lead to infertility.

\section{RF EMF exposure affects hormonal changes}

Microwave exposure disrupts the seminiferous tubules and reduces the Leydig cell population and therefore the serum testosterone concentration in rats. Leydig cells secrete testosterone, where luteinizing hormone (LH) stimulates Leydig cells to produce testosterone and maintains their function. Testosterone is responsible for feedback control of the LH secretion at both the hypothalamus and pituitary. This pituitary hormone promotes the secretion of testosterone by the Leydig cells, which are the interstitial cells situated between the seminiferous tubules [85]. Leydig cells are among the most susceptible cells to EMW and injury to these cells may affect spermatogenesis [86]. Kumar et al. have reported a decline in the level of testosterone after $10 \mathrm{GHz}$ of microwave exposure, where significant differences in exposed animals $(1.4 \pm 0.8 \mathrm{ng} / \mathrm{ml})$ were found by comparing to the sham-exposed one $(4.1 \pm 1.4 \mathrm{ng} / \mathrm{ml})$ [63].

Several studies reported that testosterone is essential for spermatogenesis, formation of spermatozoa, and maintenance of structural morphology and physiology of seminiferous tubules $[87,88]$. Therefore, any changes in the level of testosterone will have detrimental effects on male fertility. Meo et al. reported that radiations may affect the state of polarization of the cellular membranes [33]. This may be responsible for distinct changes in testosterone synthesis and secretion. Since changes in serum testosterone levels may be associated with a possible effect on pineal melatonin secretion, mobile phones may cause a reduced melatonin production, which is reported in several studies [27, 89, 90]. Melatonin is an important factor in testosterone secretion because it exerts an antigonadotrophic effect mainly at the level of the hypothalamus and pituitary [91-93].

RF-EMF exposure and Genotoxicity: Many in vitro and in vivo studies showed that EMF induced genotoxic single- and double-strand DNA breaks, micronucleus formation, chromosomal abbreviations, changes in gene expression, cell proliferation and apoptosis [25, 26, 9497]. Such changes are responsible for genomic instability and promote tumorigenic effect in cells. We explore the genotoxic effect of RF EMF on sperm parameters and 
possible infertility outcome as discussed below and which is also represented in Figure 2.

\section{DNA damage}

The majority of infertile men present with DNA damage [98-100]. Apart from several other lifestyle factors, cell phone use has been identified to induce sperm DNA damages [26] as a result of an overproduction of reactive oxygen species (ROS) in men continuously using mobile phones. This may lead to the development of different pathologies including tumors, and problems in the spermatogenesis $[25,67]$.

Carrying the cell phone in the trouser pocket impairs the sperm quality. Kumar et al. has reported DNA strand break in sperm cells after exposure of the testes (the antenna position of $3 \mathrm{G}$ cell phone kept near rat testis) for $2 \mathrm{~h} /$ day for 60 days in this mode [26]. Using the Comet assay, the authors reported significant $(p<$
$0.05)$ increases in sperm DNA tail length $(138.03 \pm$ $57.84 \mu \mathrm{m})$ and DNA tail moment $(34.59 \pm 45.02 \%)$ in the exposed group as compared to the control (39.96 \pm $36.51 \mu \mathrm{m}$ and $2.75 \pm 3.08 \%$ ), respectively. Kumar et al. has also reported DNA damage when animals were exposed $2 \mathrm{~h}$ /day for 45 days to $10 \mathrm{GHz}$ of microwaves exposure [63]. The authors reported a significant $(\mathrm{p}<0.05)$ increase in tail intensity $(15.1 \pm 13.1 \%)$, tail length (154.4 $\pm 49.4 \mu \mathrm{m})$ and tail moment $(21.6 \pm 14.7 \%)$ in the exposed group compared to the control group, where tail intensity $(1.5 \pm 2.01 \%)$, tail length $(56.6 \pm 14.2 \mu \mathrm{m})$ and tail movement $(4.0 \pm 0.5 \%)$ were obtained. The parameters like tail length is the distance of DNA migration from the body of nuclear core; tail moment is the product of the tail length and fraction of total DNA in the tail and tail intensity represents the number of relaxed/ broken pieces of DNA in the tail. It is interesting to note that with the duration of the exposure and an increasing

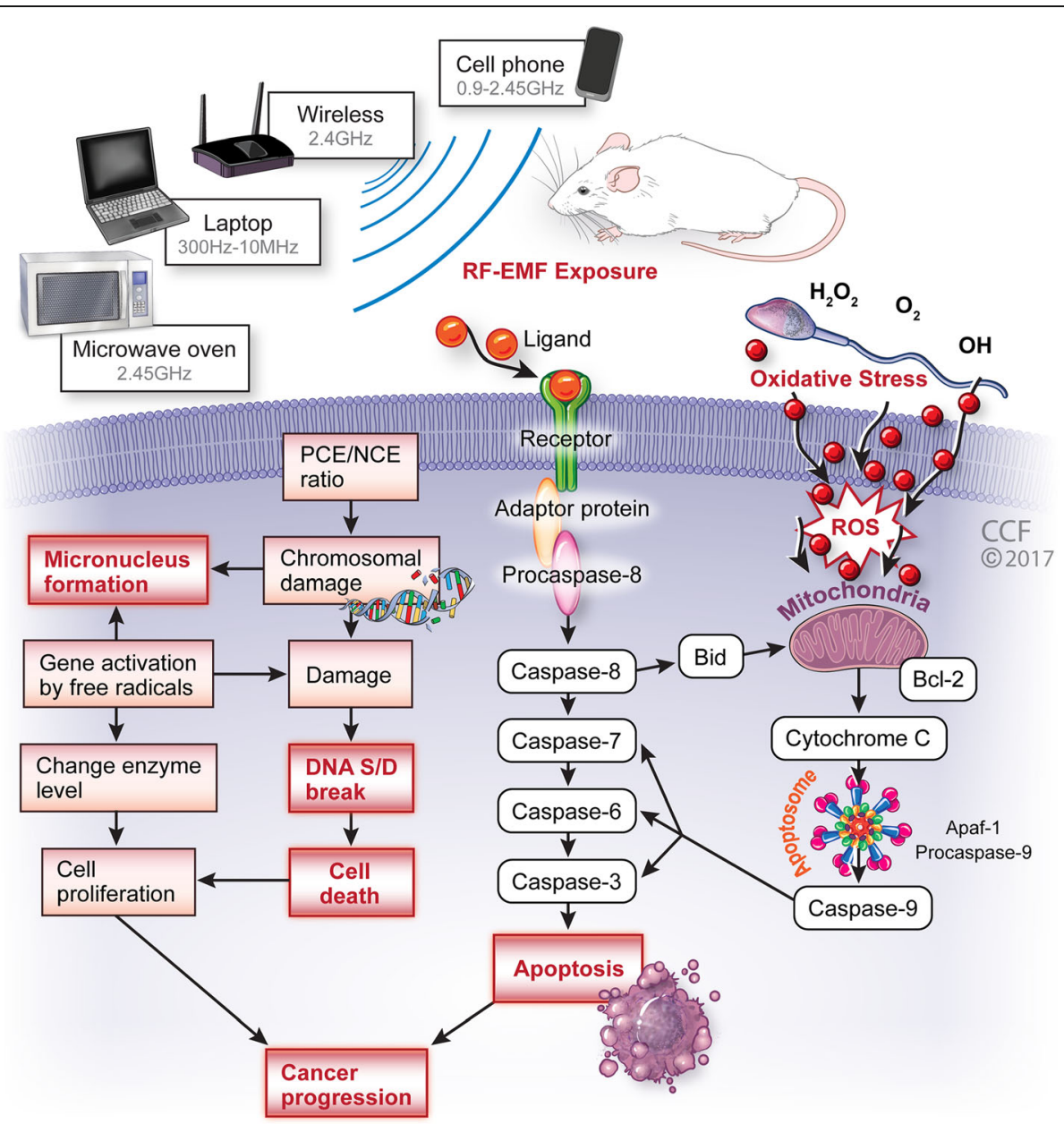

Fig. 2 An overview on the effects of RF EMF exposure, emitting from various sources (cell phone, microwave oven, Wi-Fi, Laptop) on genotoxic parameters. The proposed mechanism suggesting radiation-induced oxidative damage may increase DNA damage, micronuclei formation and leading cancer progression. This has been linked to distorted sperm head and mitochondrial sheath in sperm tail which leads to apoptosis and finally cancer progression 
power density (emitted radiation during exposure) the magnitude of the effect also increased.

Recently, Meena et al. have reported a significant increase in sperm DNA damage after whole body microwave exposure at $2.45 \mathrm{GHz}$ for $2 \mathrm{~h}$ /day for 45 days by measuring DNA tail length and tail movement by using the comet assay [25]. RF-EMF of $2.45 \mathrm{GHz}$ exposure caused rearrangement of DNA segments and breakage of DNA in the testes [101]. Therefore, any changes at DNA level in sperm or any other cell type may have mutagenic or tumorigenic effects.

Several other pilot studies (in vitro) on the effect of 2.45 GHz RFR on human ejaculated semen found changes in sperm motility and DNA fragmentation $[8$, 102]. Studies using RF-EMF of $900 \mathrm{MHz}$ and $1.7 \mathrm{GHz}$ revealed induced DNA breakage in cauda epididymal spermatozoa and embryonic stem cells in mice $[3,103]$. Since the male germ cell is very compact and rigid in nature, DNA damage due to EMF is significant. However, a short-term effect of RF exposure is not strong and effective enough to cause any genomic level of changes because this damage may be the result of cumulative effects of repeated exposure [16]. Yet, it is also suggested that oxidative stress plays a key role in the underlying mechanism of sperm DNA fragmentation.

\section{Micronuclei, chromosomal damages and genomic instability} Micronuclei (MN) is a well-known biomarker of genotoxic events where an induced MN formation led to cell death, genomic instability, or cancer development [104]. Ionizing radiation is also a well-known inducer of genomic instability [3]. Adiga et al. reported that the exposure to ionizing radiation in mice could cause sperm DNA fragmentation and lead to transgenerational genomic instability in the offspring [105]. Radiation induced genomic instability (IGI) can be defined as delayed de novo appearance of genetic alterations after multiple cell generations. Micronuclei have been used to measure radiation-induced chromosomal damage in bone marrow and peripheral blood erythrocytes in rats [63].

Recently, Kesari et al. reported a significant increase in polychromatic erythrocyte (PCE) in a 3G mobile phone-exposed group (132.66 \pm 8.62 micro-nucleated PCE/1000 erythrocytes) as compared to the sham exposed $(15 \pm 3.56$ micro-nucleated $\mathrm{PCE} / 1000$ erythrocytes, $P<0.002)[96]$. Similarly, a flowcytometric analysis showed that increased micronuclei formation with the ratio of PCE/NCE (normochromatic erythrocyte) after exposure to $3 \mathrm{G}$ mobile phone $(0.24 \pm 0.02$ micro-nucleated $\mathrm{PCE} / 1000$ erythrocytes) was significantly lower as compared with the sham-exposed group $(0.56 \pm 0.05$ micro-nucleated PCE/1000 erythrocytes; $P<0.001)$. Kumar et al. have also reported a significant $(P<0.0004)$ increase by $52.75 \%$ in micronuclei formation in blood samples after $10 \mathrm{GHz}$ microwaves exposure compared to the control [63]. The measurement of micronuclei formation has been proposed as a reliable method for measuring genotoxic or cytotoxic damages "in vivo" [106].

The basic phenomenon of micronuclei formation is that during red blood cells (RBC) formation, erythroblasts expel their nucleus and damage the chromosomes in the cytoplasm of young erythrocyte (in the form of micronuclei). Due to their small size, the radiofrequency-induced $\mathrm{MN}$ are likely to arise via a clastogenic effect $[38,107]$. Micronuclei formation due to EMF is responsible for induced genomic instability [108]. Recent in vitro studies using neuronal cell lines suggest that exposure to ELF MFs may induce genomic instability after several generations $[108,109]$. Thus far, no studies have reported genomic instability after short-term exposure to RF-EMF. Therefore, it is too early to conclude that any changes due to RF-EMF with decreased sperm count, motility, chromosomal or DNA damage and micronuclei formation may lead to the genomic instability. Nevertheless, such effect after long term RF-EMF exposure detection might be serious concern.

\section{Microtubule and mitochondrial function}

The physiology of sperm is an important factor in the fertility pattern, where microtubules participates and play a crucial role in cell division, intra-cellular transport, maintenance of cell polarity and motility. Any severe changes in the sperm structure (head: nucleus, acrosome; mid piece: mitochondria; flagellum) leads to decreased sperm count, decreased motility and finally infertility. The manchette and axoneme have a very important role as being part of the formation or in development of sperm head and tail [110], of which the main constituents of the latter are microtubules [111]. Any alteration in the ultrastructure of these microtubule-based structures may cause abnormalities in the sperm tail and alter its morphology causing severe alterations in its motility and are thus associated with infertility [112].

Kesari and Behari investigated an alteration in microtubule arrangement after exposure to mobile phone radiation [28]. Results observed under transmission electron microscopy of spermatozoa from RF-exposed rats showed significant changes in the midpiece region, microtubules of axoneme, and outer dense fibers of mitochondria and membranes. These authors also reported that the sagittal section of sperm nucleus with the acrosome shows a distortion (diffusion) from membrane head. The axoneme is the inner core structure of the cilia and flagella and is composed of a typical $9+2$ pattern, two central and nine peripheral microtubules doublets. It originates from the distal centriole of the round spermatid centrosome [113]. For the generation 
of motility, the flagella and their microtubule assembly need a source of energy, where ATP hydrolysis provides the chemical energy required for production of kinetic energy, i.e. flagellar movement.

ATP is produced by the mitochondria present in the anterior section of sperm tail called the mid piece. Excess exposure of sperm to mobile phone RF-EMF causes a disruption of sperm mitochondria and resulted in production of high levels of ROS [67], which in turn are responsible for the decrease in sperm motility and the distortion of the acrosome possibly leading to an inability to penetrate oocytes, causing in infertility [28]. Figure 2 represents the possible mechanism of RF-EMF induced oxidative damage in mitochondria of sperm tail. However, several researchers reported that due to an excessive mitochondrial ROS production, the sperm cells' limited endogenous antioxidant defenses are rapidly overwhelmed, which in turn may induce oxidative damage leading to peroxidation of the sperm acrosomal membrane and diminished acrosin activity $[114,115]$.

\section{$\mathrm{RF}$ induced oxidative stress and ROS formation}

The link between RF-EMF exposure and possible health effects are associated with the production of reactive oxygen species (ROS) and as a result of that increased oxidative stress. Oxidative stress is a condition in which the natural balance between oxidants and antioxidants is derailed towards an excessive amount of oxidants in relation to the antioxidants. This condition leads to biological damage of cells, tissues and organs [116]. De Iullis et al. reported that oxidative stress might be the main factor causing an elevation in sperm chromatin/ DNA damage [67]. However, exposure to cell phone radiation may induce oxidative stress leading to enhanced lipid peroxidation and changes in the antioxidant activities in the body [117]. Although, seminal plasma has a high capacity of endogenous antioxidants in order to protect spermatozoa from oxidative damage $[118,119]$, cell phone exposure leads to the induction of oxidative stress through the generation of ROS in the sperm plasma membrane by activation of NADH oxidase and similarly the activation of leukocytes.

Spermatozoa are particularly vulnerable to RF-induced oxidative stress. Small changes in the ROS level may play an important role in sperm capacitation, the acrosome reaction, and binding to the oocyte [120]. Kesari et al. observed significantly $(P=0.035)$ increased ROS levels as expressed as $\mathrm{mg} \mathrm{H}_{2} \mathrm{O}_{2} / \mathrm{l}(58.25 \pm 10.36 \mathrm{mg} / \mathrm{l})$ in semen of rats that were exposed to mobile phone radiation. In the control group, the ROS levels were $41.78 \pm 12.93 \mathrm{mg} / \mathrm{l}$ [38]. Kumar et al. has also reported a significant increase in seminal ROS level after $10 \mathrm{GHz}$ of microwave exposure [121].
Many researchers have reported that elevated levels of ROS are cytotoxic, and may results in a loss of sperm motility, count and vitality [122-125]. Since sperm motility is directly associated with mitochondrial dysfunction, defects in sperm mitochondrial ultrastructure could be associated with decreased sperm motility in humans [126, 127].

The existence of deteriorated spermatozoa in the semen significantly increases the production of ROS and leads to mitochondrial dysfunction [128]. Since mitochondria in spermatozoa constantly supply the energy for sperm motility, any metabolic disruption in the electrons transport chain can increase the mitochondrial ROS production significantly, thus affecting sperm motility $[129,130]$. Moreover, an increased mitochondrial ROS production leads to DNA fragmentation, decreased sperm motility and viability after mobile phone exposure [67]. Hence, it is important to protect the cells from free radical attacks by scavenging these highly reactive molecules with antioxidants.

Infertile men have significantly increased seminal ROS levels as well as a reduction in the antioxidant capacity compared with fertile controls $[18,131-135]$. The formation of ROS may affect several enzymes such as superoxide dismutase (SOD), catalase (CAT) or glutathione peroxidase (GPx), which are found in seminal fluid and protect spermatozoa against the assault of ROS. Kesari and Behari [28] and Kesari et al. [38] have reported a decrease in glutathione and superoxide production after RF-EMF exposure at different frequency and power levels where the decreased glutathione level during sperm production correlated with disruption in the membrane integrity of spermatozoa as consequence of induced oxidative stress.

\section{RF-EMF exposure affects the reproductive endocrine system}

RF-EMF exposure may not only disrupt brain functions which in turn may lead to negative effects on the reproductive endocrine system as the central nervous system (CNS), particularly the limbic system and the hypothalamus, but also play an important role in controlling testicular hormones through neuro-endocrine feedback mechanisms via gonadotropin releasing hormone $(\mathrm{GnRH})$ stimulating follicle-stimulating hormone (FSH) and LH as key hormones released from the pituitary gland. RF-EMF exposure can affect the release of adrenocorticotropic hormone, growth hormone, thyroid stimulating hormone, $\mathrm{FSH}$, and $\mathrm{LH}$ in the pituitary [136]. Therefore, any decrease in the level of FSH may negatively affect spermatogenesis. On the other hand, LH stimulates Leydig cells to produce testosterone; therefore a decrease in the level of the testosterone may affect sexual differentiation in the fetus and spermatogenesis in the 
adult. FSH stimulates the Sertoli cells, thereby activates the seminiferous tubules, resulting in the production of sperm as well as the conversion of testosterone to estradiol [137]. Researchers reported that EMF is also responsible for the decrease of melatonin levels in the brain pineal gland [27, 138]. Oktem et al. also found decreased melatonin concentrations due to microwave radiationinduced increased oxidative stress [139]. Melatonin exerts an antigonadotrophic effect mainly at the level of the hypothalamus and pituitary $[91,92]$ and decreases the testosterone secretion in Leydig cells with relevantly decreased testicular size and insufficient testosterone production [92]. Melatonin regulates the pulse of LH secretion in the hypothalamus, influencing gonadotropin FSH and LH release. Eventually, this can alter the production of gonadal sex steroids, resulting in changes in the reproductive cycle [140, 141].

A disrupted endocrine system may pose a great risk during prenatal and early postnatal development especially the brain development phase as reported by Sharma et al. [45]. These authors exposed pregnant female mice to $10 \mathrm{GHz}$ microwave radiation and found that the radiation affected the neonatal brain much higher after exposure at 0.25 days of gestation as compared to 11.25 days, indicating the sensitivity of the brain to high frequency radiation during the early developmental phase. More interestingly, Kesari and Behari have reported that progeny from RF-exposed ( $2 \mathrm{~h}$ /day for 45 days) rats showed significant decreases in number and weight as compared with control animals [28].

\section{Consequences of radiotherapy on male fertility}

Vakalopoulos et al. [142] reported that cancer treatments, including surgery, radiotherapy and chemotherapy, could have a transitory as well as a permanent detrimental impact on male fertility. However, in patients with testicular cancer, radiotherapy has been found more deleterious to fertility than chemotherapy [143], an observation which has not been confirmed by some other authors [144, 145]. The doses applied for radiotherapy range from 3000 to 7000 cGy and are found to have mutagenic, teratogenic and embryotoxic effects [146, 147]. The constant production of sperm in the germinal epithelium renders the testes as a prime target for radiotherapy, which affects the gonads by damaging sperm production, thus leading to infertility [148]. The extent of the damage caused by radiation depends on the dosage and exposure methods (radiotherapy alone or in combination with other treatment methods). Since spermatogonia are mitotically active, the dividing spermatogonia are most vulnerable to radiation treatment [149]. The estimated dosage of radiation causing adverse effects and a reduction in the number of spermatogonia and daughter cells has been reported as between 0.1-1.2 Gy, while irreversible damage occurs at 4 Gy and a decrease in sperm count is obvious at 46 Gy [150]. Damage to Leydig cells is generally associated with infertility [151]. However, these cells are more resistant to radiation-induced injury [152].

During the first 50-60 days after moderate levels of irradiation (1.5-2 Gy dose), the sperm count is reduced up to $50 \%$, which may even lead to azoospermia after moderate-to-high dose irradiation [153, 154, 148]. Post-radiation sperm cell damage is most severe 4 to 6 months after completion of a radiotherapy leading to azoospermia [155]. Whereas, in some men, low sperm counts, decreased motility, and increased rates of chromosomal abnormalities were observed after irradiation [156, 157]. A single dose of radiation administered in multiple treatments, lowers the semen volume and sperm count, which may depend on the dose applied. The recovery period for normal semen volume and sperm count could be 9-18 months if the radiation dose is below $1 \mathrm{~Gy}$, about 30 months after 2-3 Gy exposure and 5 or more years for a dose of 4-6 Gy [148, 158, 159]. In general, the extent of the damage and thus the degree of fertility impairment depends on the radiation dosage. Essentially, any electromagnetic radiation including those deriving from cell phone, cell phone towers, laptop, microwave oven etc. may lead to detrimental effects on fertility. However, the harmful effects of electromagnetic radiation have not been proven in human studies due to inherent limitations associated with carrying out human studies. Therefore, more innovative basic research is needed to decipher and prove the harmful effects of electromagnetic radiation on male fertility.

\section{Protective measures of RF-EMF exposure}

The role of antioxidants in cell protection against RF-EMF-induced oxidative stress has been discussed earlier. Melatonin, N-acetyl-cysteine, and green tea or medicinal plant leaf extracts have antioxidative properties to protect the cells from any damage. The antioxidative properties of melatonin were reported first by Ianas et al. [160] and subsequently by others [25, 161-163]. Melatonin reduces oxidative stress and protects membrane lipids, cytosolic proteins, nuclear and mitochondrial DNA from oxidative damage [164]. In addition, it acts as potent antioxidant to detoxify ROS and stimulates antioxidative enzymes [139, 165]. Moreover, melatonin not only protects the cells from EMF-induced oxidative damage, but also prevents a decline in the mitochondrial membrane potential, which may trigger mitochondrial transition pore opening and triggering the apoptotic cascade [166-168]. A study by Meena et al. reported a protective role of melatonin against microwave radiations [25]. Authors exposed the animals for $2 \mathrm{~h}$ per day for 45 days. Melatonin was found to provide 
protection from oxidative damage as indicated by significant decreases $(p<0.001)$ in the levels of malondialdehyde and ROS $(p<0.01)$. Melatonin treatment also reversed the effects of EMF for sperm count, testosterone level and DNA fragmentation [25].

Consumption of green tea (Camellia sinensis), a rich source of polyphenolic compounds, shows promising antioxidant effects $[55,56]$ as these compounds have anti-inflammatory and anti-oxidative properties. It can also protect from many kinds of diseases due to its anti-proliferative, anti-mutagenic, anti-bacterial, and chemo-preventive properties [169-172]. Reportedly, RF-EMF induces oxidative stress and promotes sperm dysfunctions [10, 25, 26]. However, the consumption of green tea has been found to improve the quality of male and female gametes [173]. These polyphenols are potentially strong to inhibit ROS formation and have a preventative role against RF radiations. Daily consumption of green tea extract could protect the cardiovascular system [174] and lower blood glucose and cholesterol levels [175]. Recently, Roychoudhury et al. suggested that the supplementation of green tea in males could significantly improve sperm parameters by reducing oxidative stress [173]. Several other studies also support that consumption of green tea may alleviate oxidative stress and maintain reproductive health $[176,177]$. Kim and Rhee reported that supplementation with green tea catechins significantly reduced the oxidative damage in the microwave exposed group [178]. Zahedifar and Baharara have also reported that green tea has an inhibitory effect and it decreases the average number of micronuclei in cell phone exposed mice [179].

\section{Conclusion}

Studies reveal that the exposure to cell phones, microwave ovens, laptops, or Wi-Fi produces deleterious effects on the testes, which may affect sperm count, morphology, motility, an increased DNA damage, causing micronuclei formation and genomic instability, as well as disruptions in protein kinases, hormones and antioxidative enzymes. Such effects were found to be responsible for infertility due to an over-production of ROS in exposed cells. Studies suggest that the abnormalities reported due to RF-EMF-exposure depend on physical parameters such as duration of the exposure, distance to the source of radiation, power density, and depth of the penetration. Unfortunately, current studies are unable to suggest a true mechanism of how RF-EMF radiation affects the male reproductive system. Therefore, more studies are necessary to provide better evidence of RF-EMF radiations emitted from cell phones, microwaves, Wi-Fi and Wi-Fi-connected laptops, which can be provided by in vitro and in vivo studies in combination with physical bio-modeling. Moreover, very limited research is available on protective measures, which actually worsens the problem as the electro-smog pollution is constantly increasing and one could then expect even more health problems including increased rates of male infertility due to such kind of radiation. On the other hand, possible protective effects of various antioxidants should be elucidated. Yet, this would only address the problem at symptomatic level.

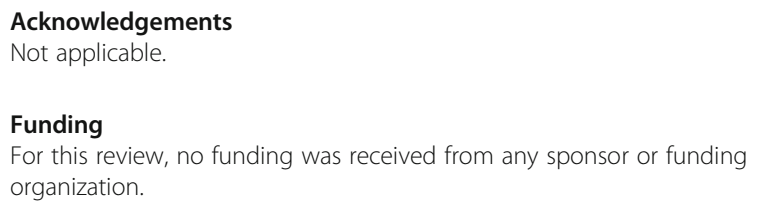

Availability of data and materials

All material is available and relevant permissions have been given.

Authors' contributions

AA and KK had the idea for this review; KK wrote the first draft of this manuscript; $\mathrm{RH}$ and AA critically reviewed the manuscript and added relevant information. All authors read and approved the final manuscript.

Ethics approval and consent to participate

This is a review and did not need ethical clearance.

Consent for publication

All mentioned authors were involved in the writing of this review and gave consent for its publication.

\section{Competing interests}

The authors declare that they have no competing interests.

\section{Publisher's Note}

Springer Nature remains neutral with regard to jurisdictional claims in published maps and institutional affiliations.

\section{Author details}

'Department of Applied Physics, Aalto University, Espoo, Finland. ${ }^{2}$ American Center for Reproductive Medicine, Cleveland Clinic, Mail Code X-11, 10681 Carnegie Avenue, Cleveland, OH 44195, USA. ${ }^{3}$ Department of Medical Bioscience, University of the Western Cape, Robert Sobukwe Road, Bellville 7535 , South Africa.

Received: 11 August 2017 Accepted: 24 October 2018

Published online: 09 December 2018

\section{References}

1. Prausnitz S, Susskind C. Effects of chronic microwave irradiation on mice. Ire Trans Biomed Electron. 1962;9:104-8.

2. Bullock J, Boyle J, Wang MB, Ajello RR. Physiology. Pennsylvania: Harwal Publishing Company; 1984.

3. Baverstock K. Radiation-induced genomic instability: a paradigm-breaking phenomenon and its relevance to environmentally induced cancer. Mutat Res. 2000;454:89-109.

4. Martin RH, Hildebrand K, Yamamoto J, Rademaker A, Barnes M, Douglas G, Arthur K, Ringrose T, Brown IS. An increased frequency of human sperm chromosomal abnormalities after radiotherapy. Mutat Res. 1986;174:219-25.

5. Fischbein A, Zabludovsky N, Eltes F, Grischenko V, Bartoov B. Ultramorphological sperm characteristics in the risk assessment of health effects after radiation exposure among salvage workers in Chernobyl. Environ Health Perspect. 1997;105:1445-9.

6. Xu G, Intano GW, McCarrey JR, Walter RB, McMahan CA, Walter CA. Recovery of a low mutant frequency after ionizing radiation-induced mutagenesis during spermatogenesis. Mutat Res. 2008;654:150-7. 
7. Yousif L, Blettner M, Hammer GP, Zeeb H. Testicular cancer risk associated with occupational radiation exposure: a systematic literature review. J Radiol Prot. 2010;30:389-406.

8. Avendano C, Mata A, Sarmiento CS, Doncel G. Use of laptop computers connected to internet through Wi-fi decreases human sperm motility and increases sperm DNA fragmentation. Fertil Steril. 2012;97:39-45.

9. Kesari K, Kumar S, Behari J. Mobile phone usage and male infertility in Wistar rats. Ind J Exp Biol. 2010:48:987-92.

10. Kesari KK, Kumar S, Nirala J, Siddiqui MH, Behari J. Biophysical evaluation of radiofrequency electromagnetic field effects on male reproductive pattern. Cell Biochem Biophys. 2013;65:85-96.

11. McGill JJ, Agarwal A. The impact of cell phone, laptop computer, and microwave oven usage on male fertility. In: du Plessis SS, et al., editors. Male infertility: a complete guide to lifestyle and environmental factors; 2014. p. 161-77. https://doi.org/10.1007/978-1-4939-1040-3 11. C Springer Science +Business Media New York 2014

12. Behari J: Biological correlates of low-level electromagnetic-field exposure, general, Applied and systems toxicology. Wiley, Book chapter 2009, 109 https://doi.org/10.1002/9780470744307.gat171

13. Baan R, Grosse Y, Lauby-Secretan B, El Ghissassi F, Bouvard V, BenbrahimTallaa L, Guha N, Islami F, Galichet L, Straif K. Carcinogenicity of radiofrequency electromagnetic fields. Lancet Oncol. 2011;12:624-6.

14. IARC Monographs on the Evaluation of Carcinogenic Risks to Humans, Volume 102. Non-lonizing radiation, Part II: Radiofrequency electromagnetic fields [includes mobile telephones]. Lyon: IARC; 2013. http://monographs. iarc.fr/ENG/Monographs/vol102/mono102.pdf

15. International Commission on Non-lonizing Radiation Protection. Guidelines for limiting exposure to time-varying electric, magnetic, and electromagnetic fields (up to $300 \mathrm{GHz}$ ). Health Phys. 1998;74:494-522.

16. Agarwal A, Singh A, Hamada A, Kesari KK. Cell phones and male infertility: a review of recent innovations in technology and consequences. Int Braz J Urol. 2011:37:432-54

17. Agarwal A, Deepinder F, Sharma RK, Ranga G, Li J. Effect of cell phone usage on semen analysis in men attending infertility clinic: an observational study. Fertil Steril. 2007;89:124-8.

18. Desai N, Sharma R, Makker K, Sabanegh E, Agarwal A. Physiologic and pathologic levels of reactive oxygen species in neat semen of infertile men. Fertil Steril. 2009:92:1626-31.

19. Mailankot M, Kunnath AP, Jayalekshmi H, Koduru B, Valsalan R. Radio frequency electromagnetic radiation (RF-EMR) from GSM (0.9/1.8 $\mathrm{GHz}$ )mobile phones induces oxidative stress and reduces sperm motility in rats. Clinics (Sao Paulo). 2009;64:5615.

20. Agarwal A, Deepinder F, Sharma RK, Ranga G, Li J. Effect of cell phone usage on semen analysis in men attending infertility clinic: an observational study. Fertil Steril. 2008;89:124-8.

21. Pandey N, Giri S, Das S, Upadhaya P. Radiofrequency radiation ( $900 \mathrm{MHz}$ )induced DNA damage and cell cycle arrest in testicular germ cells in swiss albino mice. Toxicol Ind Health. 2017;33:373-84.

22. Odacı E, Özyılmaz C. Exposure to a $900 \mathrm{MHz}$ electromagnetic field for 1 hour a day over 30 days does change the histopathology and biochemistry of the rat testis. Int J Radiat Biol. 2016;91:547-54

23. Zalata A, El-Samanoudy AZ, Shaalan D, El-Baiomy Y, Mostafa T. In vitro effect of cell phone radiation on motility, DNA fragmentation and clusterin gene expression in human sperm. Int J Fertil Steril. 2015;9:129-36.

24. Gorpinchenko I, Nikitin O, Banyra O, Shulyak A. The influence of direct mobile phone radiation on sperm quality. Cent European J Urol. 2014;67:65-71.

25. Meena R, Kumari K, Kumar J, Rajamani P, Verma HN, Kesari KK. Therapeutic approaches of melatonin in microwave radiations-induced oxidative stressmediated toxicity on male fertility pattern of Wistar rats. Electromagn Biol Med. 2014;33:81-91.

26. Kumar S, Nirala JP, Behari J, Paulraj R. Effect of electromagnetic irradiation produced by $3 \mathrm{G}$ mobile phone on male rat reproductive system in a simulated scenario. Indian J Exp Biol. 2014;52:890-7.

27. Kesari KK, Kumar S, Behari J. 900-MHz microwave radiation promotes oxidation in rat brain. Electromagn Biol Med. 2011;30:219-34.

28. Kesari KK, Behari J. Evidence for mobile phone radiation exposure effects on reproductive pattern of male rats: role of ROS. Electromagn Biol Med. 2012; 31:213-22.

29. Kumar S, Kesari KK, Behari J. The therapeutic effect of a pulsed electromagnetic field on the reproductive patterns of male Wistar rats exposed to a 2.45-GHz microwave field. Clin (Sao Paulo). 2011;66:1237-45.
30. Kumar S, Kesari KK, Behari J. Influence of microwave exposure on fertility of male rats. Fertil Steril. 2011:15:1500-2.

31. Kesari KK, Behari J. Effects of microwave at $2.45 \mathrm{GHz}$ radiations on reproductive system of male rats. Toxicol Environ Chem. 2010;92:1135-47.

32. Kesari KK, Behari J. Microwave exposure affecting reproductive system in male rats. Appl Biochem Biotechnol. 2010;162:416-28.

33. Meo SA, Al-Drees AM, Husain S, Khan MM, Imran MB. Effects of mobile phone radiation on serum testosterone in Wistar albino rats. Saudi Med J. 2010;31:869-73.

34. Agarwal A, Desai NR, Makker K, Varghese A, Mouradi R, Sabanegh E, Sharma $R$. Effects of radiofrequency electromagnetic waves (RF-EMW) from cellular phones on human ejaculated semen: an in vitro pilot study. Fertil Steril. 2009:92:1318-25.

35. Mailankot M, Kunnath AP, Jayalekshmi H, Koduru B, Valsalan R. Radio frequency electromagnetic radiation (RF-EMR) from GSM $(0.9 / 1.8 \mathrm{GHz})$ mobile phones induces oxidative stress and reduces sperm motility in rats. Clinics. 2009:64:561-5.

36. De luliis GN, King BV, Aitken RJ. Electromagnetic radiation and oxidative stress in the male germ line. In: Agarwal A, Aitken RJ, Alvarez JG, editors. Studies on Men's health and fertility. New York: Humana Press; 2012. p. 119-30.

37. Yan JG, Agresti M, Bruce T, Yan YH, Granlund A, Matloub HS. Effects of cellular phone emissions on sperm motility in rats. Fertil Steril. 2007;88: 957-64

38. Kesari KK, Kumar S, Behari J. Effects of radiofrequency electromagnetic wave exposure from cellular phones on the reproductive pattern in male Wistar rats. Appl Biochem Biotechnol. 2011;164:546-59.

39. Sharma A, Kesari KK, Verma HN, Sisodia R. Neurophysiological and behavioral dysfunctions after electromagnetic field exposure: a dose response relationship. In: Kesari K, editor. Perspectives in environmental toxicology. Basel, Switzerland: Springer International Publishing; 2017. p. $01-$ 30. https://doi.org/10.1007/978-3-319-46248-6_1.

40. Lai $H$, Singh NP. Magnetic-field-induced DNA strand breaks in brain cells of the rat. Environ Health Perspect. 2004:112:687-94.

41. Lai H, Singh NP. Melatonin and N-tert-butyl-alpha-phenylnitrone block 60$\mathrm{Hz}$ magnetic field-induced DNA single and double strand breaks in rat brain cells. J Pineal Res. 1997;22:152-62.

42. Simko M. Cell type specific redox status is responsible for diverse electromagnetic field effects. Curr Med Chem. 2007;14:1141-52.

43. Bhat MA. Effects of Electromagnetic Waves Emitted by Mobile Phones on Male Fertilit. Computer Engineering and Intelligent Systems. 2013;4(3):51-64

44. How cell-phone radiation works. HowStuffWorks, a division of InfoSpace Holdings LLC, a System1 Company. 2001; Available at: https://electronics. howstuffworks.com/cell-phone-radiation1.htm.

45. Sharma A, Kesari KK, Saxena VK, Sisodia R. The influence of prenatal $10 \mathrm{GHz}$ microwave radiation exposure on a developing mice brain. Gen Physiol Biophys. 2017:36:41-51.

46. Barnett J, Timotijevic L, Shepherd R, Senior V. Public responses to precautionary information from the Department of Health (UK) about possible health risks from mobile phones. Health Policy. 2007:82:240-50

47. Kang XK, Li LW, Leong MS, Kooi PS. A method of moments study of SAR inside spheroidal human head and current distribution among handset wireless antennas. J Electromag Waves Appl. 2001:15:61.

48. Dimbylow PJ, Mann SM. SAR calculations in an anatomically realistic model of the head for mobile communication transceivers at $900 \mathrm{MHz}$ and 1.8 GHz. Phy Med Biol. 1994;39:1537-44.

49. Rothman KJ, Chou CK, Morgan R, Balzano Q, Guy AW, Funch DP. Assessment of cellular telephone and other radio frequency exposure for epidemiologic research. Epidemiology. 1996;7:291-8.

50. Seyhan N, Guler G. Review of in vivo static and ELF electric fields studies performed at Gazi biophysics department. Electromag Biol Med. 2006;25: $307-23$

51. Odacı E, Bas O, Kaplan S. Effects of prenatal exposure to a $900 \mathrm{MHz}$ electromagnetic field on the dentate gyrus of rats: a stereological and histopathological study. Brain Res. 2008;1238:224-9.

52. Lee HJ, Pack HJ, Kim TH, Kim N, Choi SY, Lee JS, Kim SH, Lee YS. The lack of histological changes of CDMA cellular phone-based radiofrequency on rat testis. Bioelectromagnetics. 2010:31:528-34.

53. Ulubay M, Yahyazadeh A, Deniz ÖG, KIvrak EG, Altunkaynak BZ, Erdem G, Kaplan S. Effects of prenatal $900 \mathrm{MHz}$ electromagnetic field exposures on the histology of rat kidney. Int J Radiat Biol. 2015;9:35-41. 
54. Türedi S, Hancı H, Topal Z, Ünal D, Mercantepe T, Bozkurt I, Kaya H, Odacı E. The effects of prenatal exposure to a $900-\mathrm{MHz}$ electromagnetic field on the 21-day-old male rat heart. Electromag Biol Med. 2015;34(4):390.

55. Chandra A, Martinez GM, Mosher WD, Abma JC, Jones J. Fertility, family planning, and reproductive health of U.S. women: data from the 2002 national survey of family growth. Vital Health Stat. 2005;25:1-160.

56. Homan GF, Davies M, Norman R. The impact of lifestyle factors on reproductive performance in the general population and those undergoing infertility treatment: a review. Hum Reprod Update. 2007;13:209-23.

57. Al-Akhras MA, Elbetieha A, Hasan MK, Al-Omari I, Darmani H, Albiss B. Effects of extremely low frequency magnetic field on fertility of adult male and female rats. Bioelectromagnetics. 2001;22:340-4.

58. Lee JS, Ahn SS, Jung KC, Kim YW, Lee SK. Effects of $60 \mathrm{~Hz}$ electromagnetic field exposure on testicular germ cell apoptosis in mice. Asian J Androl. 2004;6:29-34.

59. Kim YW, Kim SH, Lee JS, Kim YJ, Lee SK, Seo JN Jung KC, Kim N, Gimm Y. Effects of $60 \mathrm{~Hz} 14 \mu \mathrm{T}$ magnetic fi eld on the apoptosis of testicular cell in mice. Bioelectromagnetics. 2009;30:66-72.

60. Li DK, Yan B, Li Z, Gao E, Miiao M, Gong D, Weng X, Ferber JR, Yuan W. Exposure to magnetic fields and the risk of poor sperm quality. Reproduct Toxicol. 2010;29:86-92.

61. Fejes I, Z á vaczki Z, Szöllosi J, Koloszár S, Daru J, Kovács L, P ál A. Is there a relationship between cell phone use and semen quality? Arch Androl. 2005; 51:385-93.

62. Heynick LN, Merritt JH. Radiofrequency fields and teratogenesis. Bioelectromagnetics. 2003;(S6):S1-174-86. https://doi.org/10.1002/bem.10127.

63. Kumar S, Behari J, Sisodia R. Influence of electromagnetic fields on reproductive system of male rats. Int J Rad Biol. 2013;89(3):147.

64. Mortazavi SMJ, Tavassoli AR, Ranjbari F, Moammaiee P. Effects of laptop computers' electromagnetic field on sperm quality. J Reprod Infertil. 2010; 11:251-8.

65. Gorpinchenko I, Nikitin O, Banyra O, Shulyak A. The in uence of direct mobile phone radiation on sperm quality. Central Europ J Urol. 2014;67:65-71.

66. Jonwal C, Sisodia R, Saxena VK, Kesari KK. Effect of $2.45 \mathrm{GHz}$ microwave radiation on the fertility pattern in male mice. Gen Physiol Biophys. 2018; 37(4):453-460. https://doi.org/10.4149/gpb_2017059.

67. De luliis GN, Newey RJ, King BV, Aitken RJ. Mobile phone radiation induces reactive oxygen species production and DNA damage in human spermatozoa in vitro. PLoS One. 2009;4:e6446.

68. Al-Damegh MA. Rat testicular impairment induced by electromagnetic radiation from a conventional cellular telephone and the protective effects of the antioxidants vitamins C and E. Clinics. 2012;67:785-92.

69. Ghanbari M, Mortazavi SB, Khavanin A, Khazaei M. The effects of cell phone waves (900 MHz-GSM band) on sperm parameters and total antioxidant capacity in rats. Int J Fertility Steril. 2013;7:21-8.

70. Kilgallon SJ, Simmons LW. Image content influences men's semen quality. Biol Lett. 2005:1:252-5.

71. Al-Bayyari $\mathrm{N}$. The effect of cell phone usage on semen quality and fertility among Jordanian males. Middle East Fertil Society J. 2017:22:178-82.

72. Erogul O, Oztas E, Yildirim I, Kir T, Aydur E, Komesli G, Irkilata HC, Irmak MK Peker AF. Effects of electromagnetic radiation from a cellular phone on human sperm motility: an in vitro study. Arch Med Res. 2006;37:840-3.

73. La Vignera S, Condorelli RA, Vicari E, D'Agata R, Calogero AE. Effects of the exposure to Mobile phones on male reproduction: a review of the literature. J Androl. 2012:33:350-6.

74. Luo Y, Wang X, Chen Y, Xu S, Ding G, Shi C. Effects of electromagnetic radiation on morphology and TGF- $\beta 3$ expression in mouse testicular tissue. Toxicology. 2013;310:8-14.

75. Berensztein EB, Sciara MI, Rivarola MA, Belgorosky A. Apoptosis and proliferation of human testicular somatic and germ cells during prepuberty: high rate of testicular growth in newborns mediated by decreased apoptosis. J Clin Endocrinol Metab. 2002;87:5113-8.

76. Blanco-Rodriguez J. A matter of death and life: the significance of germ cell death during spermatogenesis. Int J Androl. 1998;21:236-48.

77. Gochfeld M. Chemical hazards. In: Levy BS, Wegman DH, Baron SL, Sokas RK, editors. Section III (hazards exposure) chapter 13; 2006. p. 269-310.

78. Dunphy WG, Brizuela L, Beach D. The Xenopus cdc2 protein is a component of MPF, acytoplasmic regulator of mitosis. Cell. 1988;54:423-31.

79. Gautier J, Norbury C, Lohka M, Nuese P, Mailer J. Purified maturationpromoting factor contains the product of a Xenopus homolog of the fission yeast cell cycle control gene cdc2. Cell. 1988;54:433-9.
80. Naor Z, Breitbart H. Protein kinase $C$ and mammalian spermatozoa acrosome reaction. TEM. 1997:8:337-42.

81. White D, de Lamirande $E$, Gagnon C. Protein kinase $C$ is an important signaling mediator associated with motility of intact sea urchin spermatozoa. J Exp Biol. 2007;210:4053-64.

82. Ohkusu K, Isobe K, Hidaka H, Nakashima I. Elucidation of the protein kinase C-dependent apoptosis pathway in distinct of T lymphocytes in MRL-Ipr/Ipr mice. Eur J Immunol. 1986;25:3180-6.

83. Wallimann $\mathrm{T}$, Moser H, Zurbriggen B, Wegmann G, Eppenberger HM. Creatine kinase isozymes in spermatozoa. J Muscle Res Cell Motil. 1986;7:25-34.

84. Vigue C, Vigue L, Huszar G. Adenosine triphosphate (ATP) concentrations and ATP/adenosine diphosphate ratios in human sperm of normospermic oligospermic, and asthenospermic specimens and in their swim-up fractions: lack of correlation between ATP parameters and sperm creatine kinase concentrations. J Androl. 1992;13:305-11.

85. Dohle GR. Male infertility in cancer patients: review of the literature. Int J Urol. 2010;17:327-31

86. Wang SM, Wang DW, Peng RY, Gao YB, Yang Y, Hu WH, et al. Effect of electromagnetic pulse irradiation on structure and function of Leydig cells in mice. Zhonghua Nan Ke Xue. 2003:9:327-30.

87. Sharpe R. Regulation of spermatogenesis. In: Knobil ENJ, editor. The physiology of reproduction. New York: Raven Press; 1994. p. 1363-434

88. Steinberger E. Hormonal control of mammalian spermatogenesis. Physiol Rev. 1971:51:1-22

89. Burch JB, Reif JS, Noonan CW, Ichinose T, Bachand AM, Koleber TL, et al. Melatonin metabolite secretion among cellular telephone users. Int J Radiat Biol. 2002:78:1029-36.

90. Jarupat S, Kawabata A, Tokura H, Borkiewicz A. Effects of the $1900 \mathrm{MHz}$ electromagnetic field emitted from cellular phone on nocturnal melatonin secretion. J Physiol Anthropol. 2003;22:61-3

91. Jackson FL, Heindel JJ, Preslock JP, Berkowitz AS. Alterations in hypothalamic content of luteinizing hormone-releasing hormone associated with pineal mediated testicular regression in the golden hamster. Biol Reprod. 1984;31:436-45.

92. Bittman EL, Kaynard AH, Olster DH, Robinson JE, Yellow SM, Karsch FJ. Pineal melatonin mediates photoperiodic control of pulsatile luteinizing hormone secretion in the ewe. Neuroendocrinology. 1985:40:409-18.

93. Vanecek J. Melatonin inhibits release of luteinizing hormone $(\mathrm{LH})$ via decrease of [Ca2+]i, and cyclic AMP. Physiol Res. 1998;47:329-35.

94. Diem E, Schwarz C, Adlkofer F, Jahn O, Rüdiger H. Non-thermal DNA breakage by mobile-phone radiation $(1800 \mathrm{MHz})$ in human fibroblasts and in transformed GFSH-R17 rat granulosa cells in vitro. Mutat Res. 2005;583: 178-83.

95. Schwarz C, Kratochvil E, Pilger A, Kuster N, Adlkofer F, Rüdiger HW. Radiofrequency electromagnetic fields (UMTS, 1,950 MHz) induce genotoxic effects in vitro in human fibroblasts but not in lymphocytes. Int Arch Occup Environ Health. 2008;81:755-67.

96. Kesari KK, Meena R, Nirala J, Kumar J, Verma HN. Effect of $3 \mathrm{G}$ cell phone exposure with computer controlled 2-D stepper motor on non-thermal activation of the hsp27/p38MAPK stress pathway in rat brain. Cell Biochem Biophys. 2014;68:347-58

97. Kumar S, Behari J, Sisodia R. Impact of microwave at X-band in the aetiology of male infertility. Electromagn Biol Med. 2012;31:223-32.

98. Schulte RT, OhI DA, Sigman M, Smith GD. Sperm DNA damage in male infertility: etiologies, assays, and outcomes. J Assist Reprod Genet. 2010;27: $3-12$.

99. Zini A, Bielecki R, Phang D, Zenzes MT. Correlations between two markers of sperm DNA integrity, DNA denaturation and DNA fragmentation, in fertile and infertile men. Fertil Steril. 2001a;75:674-7.

100. Zini A, Kamal K, Phang D, Willis J, Jarvi K. Biologic variability of sperm DNA denaturation in infertile men. Urology. 2001b;58:258-61.

101. Naziroglu M, Gumral N. Modulator effects of L-carnitine and selenium on wireless devices $(2.45 \mathrm{GHz})$-induced oxidative stress and electroencephalography records in brain of rat. Int J Radiat Biol. 2009;85: 680-9.

102. Oni OM, Amuda DB, Gilbert CE. Effects of radiofrequency radiation from WiFi devices on human ejaculated semen. Int J Res Rev Appl Sci. 2011;9: 292-4.

103. Nikolova T, Czyz J, Rolletschek A, Blyszczuk P, Fuchs J, Jovtchev G, et al. Electromagnetic fields affect transcript levels of apoptosis-related genes in 
embryonic stem cell-derived neural progenitor cells. FASEB J. 2005;19:1686-8.

104. Luzhna L, Kathiria P, Kovalchuk O. Micronuclei in genotoxicity assessment: from genetics to epigenetics and beyond. Front Genet. 2013;4:131.

105. Adiga SK, Upadhya D, Kalthur G, Bola SSR, Kumar P. Transgenerational changes in somatic and germ line genetic integrity of first-generation offspring derived from the DNA damaged sperm. Fertil Steril. 2010;93:2486-90.

106. Fenech M, Morley AA. Measurement of micronuclei in lymphocytes. Mutat Res. 1985;147:29-36.

107. Zotti-Martelli L, Peccatori M, Scarpato R, Migliore L. Induction of micronuclei in human lymphocytes exposed in vitro to microwave radiation. Mutat Res. 2000;472:51-8.

108. Kesari KK, Luukkonen J, Juutilainen J, Naarala J. Genomic instability induced by $50 \mathrm{~Hz}$ magnetic fields is a dynamically evolving process not blocked by antioxidant treatment. Mutat Res Genet Toxicol Environ Mutagen. 2015;794: 46-51.

109. Luukkonen J, Liimatainen A, Juutilainen J, Naarala J. Induction of genomic instability, oxidative processes, and mitochondrial activity by $50 \mathrm{~Hz}$ magnetic fields in human SH-SY5Y neuroblastoma cells. Mutat Res. 2014;760:33-41.

110. Lehti MS, Sironen A. Formation and function of the manchette and flagellum during spermatogenesis. Reproduction. 2016;151:R43-54.

111. Chemes HE, Sedo CA. Tales of the tail and sperm head aches: changing concepts on the prognostic significance of sperm pathologies affecting the head, neck and tail. Asian J Androl. 2012;14:14-23.

112. Sha YW, Ding L, Li P. Management of primary ciliary dyskinesia/Kartagener's syndrome in infertile male patients and current progress in defining the underlying genetic mechanism. Asian J Androl. 2014;16:101-6.

113. O'Donnell L, O'Bryan MK. Microtubules and spermatogenesis. Semin Cell Dev Biol. 2014;30:45-54.

114. Zalata AA, Ahmed AH, Allamaneni SS, Comhaire FH, Agarwal A. Relationship between acrosin activity of human spermatozoa and oxidative stress. Asian J Androl. 2004:6:313-8.

115. Taha EA, Ez-Aldin AM, Sayed SK, Ghandour NM, Mostafa T. Effect of smoking on sperm vitality, DNA integrity, seminal oxidative stress, zinc in fertile men. Urology. 2012;80:822-5.

116. Elsaved NM. Antioxidant mobilization in response to oxidative stress: a dynamic environmental nutritional interaction. Nutr. 2001;17:828-34

117. Awanti SM, Ingin JB, Jeevangi SR, Patil GA, Awanti BS. The effect of radiofrequency radiation emitted from mobile phones on plasma oxidants and antioxidants in mobile phone users. J Clini Diag Res. 2010;4:2758-61.

118. Fraga CG, Motchnik PA, Shigenaga MK, Helbock HJ, Jacob RA, Ames BN. Ascorbic acid protects against endogenous oxidative DNA damage in human sperm. Proc Nat Acad Sci. 1991;88:11003-6.

119. Sheikh N, Amiri I, Farimani M, Najafi R, Hadeie J. Correlation between sperm parameters and sperm DNA fragmentation in fertile and infertile men. Iran J Reprod Med. 2008;6:13-8.

120. Garrido N, Meseguer M, Alvarez J, Simon C, Pellicer A, Remohi J. Relationship among standard semen parameters, glutathione peroxidase/ glutathione reductase activity, and mRNA expression and reduced glutathione content in ejaculated spermatozoa from fertile and infertile men. Fertil Steril. 2004:82:1059-66.

121. Kumar S, Kesari KK, Behari J. Evaluation of genotoxic effects in male Wistar rats following microwave exposure. Indian J Exp Biol. 2010;48:586-92.

122. Alvarez JG, Touchstone JC, Blasco L, Storey BT. Spontaneous lipid peroxidation and production of hydrogen peroxide and superoxide in human spermatozoa. J Androl. 1987;8:338-48.

123. Plante $M$, de Lamirande $E_{,}$Gagnon $C$. Reactive oxygen species released by activated neutrophils, but not by deficient spermatozoa, are sufficient to affect normal sperm motility. Fertil Steril. 1994;62:387-93.

124. Aitken RJ, Curry BJ. Redox regulation of human sperm function: from the physiological control of sperm capacitation to the etiology of infertility and DNA damage in the germ line. Antioxid Redox Signal. 2011;14:367-81.

125. Shi T-Y, Chen G, Huang X, Yuan Y, Wu X, Wu B, et al. Effects of reactive oxygen species from activated leucocytes on human sperm motility, viability and morphology. Andrologia. 2011;44:696-703.

126. Mundy AJ, Ryder TA, Edmonds DK. Asthenozoospermia and the human sperm mid-piece. Hum Reprod. 1995;10:116-9.

127. Pelliccione F, Micillo A, Cordeschi G, D'Angeli A, Necozione S, Gandini L, Lenzi A, Francavilla F, Francavilla S. Altered ultrastructure of mitochondrial membranes is strongly associated with unexplained asthenozoospermia. Fertil Steril. 2011;95:641-6.
128. Agarwal A, Virk G, Ong C, du Plessis SS. Effect of oxidative stress on male reproduction. World J Mens Health. 2014;32:1-17.

129. Aitken RJ, Jones KT, Robertson SA. Reactive oxygen species and review sperm function -in sickness and in health. J Androl. 2012;33:1096-106.

130. Koppers AJ, Mitchell LA, Wang P, Lin M, Aitken RJ. Phosphoinositide 3kinase signalling pathway involvement in a truncated apoptotic cascade associated with motility loss and oxidative DNA damage in human spermatozoa. Biochem J. 2011;436:687-98.

131. Aitken RJ, Baker MA. Oxidative stress, sperm survival and fertility control. Mol Cell Endocrinol. 2006;250:66-9.

132. Athayde KS, Cocuzza M, Agarwal A, Krajcir N, Lucon AM, Srough M, et al. Development of normal reference values for seminal reactive oxygen species and their correlation with leukocytes and semen parameters in a fertile population. J Androl. 2007;28:613-20.

133. Moein MR, Dehghani VO, Tabibnejad N, Vahidi S. Reactive oxygen species (ROS) level in seminal plasma of infertile men and healthy donors. Iran J Reprod Med. 2007:5:51-5.

134. Guz J, Gackowski D, Foksinski M, Rozalski R, Zarakowska E, Siomek A, et al. Comparison of oxidative stress/DNA damage in semen and blood of fertile and infertile men. PLoS One. 2013;8:e68490.

135. Kullisaar T, Türk S, Kilk K, Ausmees K, Punab M, Mändar R. Increased levels of hydrogen peroxide and nitric oxide in male partners of infertile couples. Andrology. 2013;1:850-8.

136. Bortkiewicz A. A study on the biological effects of exposure mobile-phone frequency EMF. Med Pr. 2001;52:101-6.

137. Sofikitis N, Giotitsas N, Tsounapi P, Baltogiannis D, Giannakis D, Pardalidis N. Hormonal regulation of spermatogenesis and spermiogenesis. J Steroid Biochem Mol Biol. 2008;109:323-30.

138. Kesari KK, Kumar S, Behari J. Pathophysiology of microwave radiation: effect on rat brain. Appl Biochem Biotechnol. 2012;166:379-88.

139. Oktem F, Ozguner F, Mollaoglu H, Koyu A, Uz E. Oxidative damage in the kidney induced by $900-\mathrm{MHz}$ emitted mobile phone: protection by melatonin. Arch Med Res. 2005;36:350-5.

140. Lincoln GA, Maeda Kl. Reproductive effects of placing micro-implants of melatonin in the mediobasal hypothalamus and preoptic area in rams. J Endocrinol. 1992:132:201-15.

141. Malpaux B, Daveau A, Maurice F, Gayrard V, Thiery JC. Short-day effects of melatonin on luteinizing hormone secretion in the ewe: evidence for central sites of action in the mediobasal hypothalamus. Biol Reprod. 1993; 48:752-60.

142. Vakalopoulos I, Dimou P, Anagnostou I, Zeginiadou T. Impact of cancer and cancer treatment on male fertility. Hormones (Athens). 2015;14:579-89.

143. Huyghe E, Matsuda T, Daudin M, Chevreau C, Bachaud JM, Plante P, Bujan L, Thonneau P. Fertility after testicular cancer treatments: results of a large multicenter study. Cancer. 2004;100:732-7.

144. Brydøy M, Fosså SD, Klepp O, Bremnes RM, Wist EA, Wentzel-Larsen T, Dahl O. Paternity following treatment for testicular cancer. J Natl Cancer Inst. 2005;97:1580-8

145. Huddart RA, Norman A, Moynihan C, Horwich A, Parker C, Nicholls E, Dearnaley DP. Fertility, gonadal and sexual function in survivors of testicular cancer. Br J Cancer. 2005;93:200-7.

146. Pasqualotto FF, Agarwal A: Impact of cancers and treatment on male fertility: radiation effects on spermatogenesis. Fertility preservation in male Cancer patients, ed. John P. Mulhall, Linda D. Applegarth, Robert D. Oates and Peter N. Schlegel. Cambridge University Press. Cambridge University Press 2013. Chapter 12, Section 3, pp 104-109.

147. Arnon J, Meirow D, Lewis-Roness H, Ornoy A. Genetic and teratogenic effects of cancer treatments on gametes and embryos. Hum Reprod Update. 2001;7:394-403.

148. Ogilvy-Stuart A, Shalet S. Effect of radiation on the human reproductive system. Environ Health Perspect. 1993;101:109-16.

149. Biedka M, Kuźba-Kryszak T, Nowikiewicz T, Żyromska A. Fertility impairment in radiotherapy. Contemp Oncol (Pozn). 2016;20:199-204

150. Ståhl $\mathrm{O}$, Eberhard J, Jepson K, Spano M, Cwikiel M, Cavallin-Ståhl $E_{\text {, }}$ Giwercman A. Sperm DNA integrity in testicular cancer patients. Hum Reprod. 2006:21:3199-205.

151. Galarneau GJ, Nagler HM. Cost-effective infertility therapies in the ' 90 s: to treat or to cure? Contemp Urol. 1999:11:32-45.

152. Shalet SM, Tsatsoulis A, Whitehead E, Read G. Vulnerability of the human Leydig cell to radiation damage is dependent upon age. J Endocrinol. 1989; 120:161-5. 
153. Rowley MJ, Leach DR, Warner GA, Heller CG. Effect of graded doses of ionizing radiation on the human testis. Radiat Res. 1974;59:665-78.

154. Abuelhija M, Weng CC, Shetty G, Meistrich ML. Rat models of postirradiation recovery of spermatogenesis: interstrain differences. Andrology. 2013;1:206-15.

155. Mazur-Roszak M, Tomczak P, Litwiniuk M, Markowska J. Oncology and infertility: selected issues. Part I. what causes fertility disorders? Contemp Oncol. 2005;9:26-9.

156. Meistrich ML. The effects of chemotherapy and radiotherapy on spermatogenesis in humans. Fertil Steril. 2013;100:1180-6.

157. Martin RH, Hildebrand K, Yamamoto J. An increased frequency of human sperm chromosomal abnormalities after radiotherapy. Mutat Res. 1986;174: 219-25.

158. Wo J, Viswanathan A. Impact of radiotherapy on fertility, pregnancy, and neonatal outcomes in female cancer patients. Int J Radiat Oncol Biol Phys. 2009;73:1304-12.

159. Hahn E, Feingold S, Nisce L. Aspermia and recovery of spermatogenesis in cancer patients following incidental gonadal irradiation during treatment: a progress report. Radiology. 1976;119:223-5.

160. Ianas O, Olnescu R, Badescu I. Melatonin involvement in oxidative stress. Rom J Endocrinol. 1991;29:147-53.

161. Reiter RJ, Melchiorri D, Sewerynek E, et al. A review of the evidence supporting melatonin's role as an antioxidant. J Pineal Res. 1995;18:1-11.

162. Reiter RJ, Tan DX, Cabrera J, et al. Melatonin and tryptophan derivatives as free radical scavengers and antioxidants. Adv Exp Med Biol. 1999;467:37987.

163. Reiter RJ, Tan DX, Acuna-Castroviejo D, et al. Melatonin: mechanisms and actions as an antioxidant. Curr Top Biophys. 2000;24:171-83.

164. Reiter R, Tang L, Garcia JJ, Munoz-Hoyos A. Pharmacological actions of melatonin in oxygen radical pathophysiology. Life Sci. 1997:60:2255-71.

165. Ozguner F, Bardak Y, Comlekci S. Protective effects of melatonin and caffeic acid phenethyl ester against retinal oxidative stress in long-term use of mobile phone: a comparative study. Mol Cell Biochem. 2006:282:83-8.

166. Rodriguez C, Mayo JC, Sainz RM, Antolin I, Herrera F, Martin V, Reiter RJ. Regulation of antioxidant enzymes: a significant role for melatonin. J Pineal Res. 2004;36:1-9.

167. Martin M, Macias M, Escames G, Leon J, Acuna-Castroviejo D. Melatonin but not vitamins $C$ and $E$ maintains glutathione homeostasis in tert-butyl hydroperoxide induced mitochondrial oxidative stress. FASEB J. 2000;14: 1677-9.

168. Winiarska K, Fraczyk T, Melinska D, Drozak J, Bryla J. Melatonin attenuates diabetes-induced oxidative stress in rabbits. J Pineal Res. 2006;40:168-76.

169. Li MJ, Yin YC, Wang J, Jiang YF. Green tea compounds in breast cancer prevention and treatment. World J Clin Oncol. 2014a;5:520-8.

170. Rahmani AH, Al Shabrmi FM, Allemailem KS, Aly SM, Khan MA: Implications of green tea and its constituents in the prevention of cancer via the modulation of cell signalling pathway. Biomed Res Int. 2015;1-12. https:// doi.org/10.1155/2015/925640.

171. Schramm L. Going green: the role of the green tea component EGCG in chemoprevention. J Carcinog Mutagen. 2013:4:1000142.

172. Yang CS, Lambert JD, Sang S. Anti-oxidative and anticarcinogenic activities of tea polyphenols. Arch Toxicol. 2009;83:11-21.

173. Roychoudhury S, Agarwal A, Virk G, Cho CL. Potential role of green tea catechins in the management of oxidative stress-associated infertility. Reprod BioMed Online. 2017. https://doi.org/10.1016/j.rbmo.2017.02.006.

174. Basu A, Lucas EA. Mechanisms and effects of green tea on cardiovascular health. Nutr Rev. 2007;65:361-75.

175. Hara Y. Physiological functions of tea polyphenols: part 2. Am Biotechnol Lab. 1994;12:18.

176. Galleano M, Verstraeten SV, Oteiza PI, Fraga CG. Antioxidant actions of flavonoids: thermodynamic and kinetic analysis. Arch Biochem Biophys. 2010;501:23-30.

177. Perron NR, Brumaghim JL. A review of the antioxidant mechanisms of polyphenol compounds related to iron binding. Cell Biochem Biophys. 2009:53:75-100

178. Kim MJ, Rhee SJ. Green tea catechins protect rats from microwave-induced oxidative damage to heart tissue. J Med Food. 2004;7:299-304.

179. Zahedifar Z, Baharara J. Effect of green tea extract in reducing genotoxic injuries of cell phone microwaves on bone marrow. Zahedan J Res Med Sci. 2013:15:39-44.

\section{Ready to submit your research? Choose BMC and benefit from:}

- fast, convenient online submission

- thorough peer review by experienced researchers in your field

- rapid publication on acceptance

- support for research data, including large and complex data types

- gold Open Access which fosters wider collaboration and increased citations

- maximum visibility for your research: over $100 \mathrm{M}$ website views per year

At BMC, research is always in progress.

Learn more biomedcentral.com/submissions 